\title{
PENGARUH MODEL PEMBELAJARAN TIPE THINK TALK WRITE TERINTEGRASI KEARIFAN LOKAL BERBASIS OUTCAME BASED EDUCATION (OBE) MELALUI PENGUNAAN MEDIA ONLINE TERHADAP LITERASI SAINS PESERTA DIDIK
}

\section{THE INFLUENCE OF THE THINK TALK WRITE TYPE OF LEARNING MODEL INTEGRATED BY LOCAL WISDOM BASED ON THE OUTCOME BASED EDUCATION THROUGH THE USE OF ONLINE MEDIA ON SCIENCE LITERACY OF STUDENTS}

\author{
Juhaeri’ah*, Dadi Setiadi, Baiq Sri Handayani, dan I Putu Artayasa \\ Program Studi Pendidikan Biologi, Jurusan Pendidikan MIPA, FKIP Universitas Mataram \\ *Email: jiuhaeriah94@gmail.com
}

Diterima: 22 Februari 2021. Disetujui: 10 Mei 2021. Dipublikasikan: 2 Juni 2021

\begin{abstract}
Abstrak: Penelitian ini bertujuan untuk mengetahui (1) perbedaan antara nilai rata-rata pretest dan postest kemampuan literasi sains dengan menerapkan model pembelajaran think talk write terintegrasi kearifan lokal berbasis outcame based education melalui penggunaan media online peserta didik di SMA Negeri 1 Labuapi; (2) apakah penerapan model pembelajaran think talk write terintegrasi kearifan lokal berbasis outcame based education melalui penggunaan media online efektif dalam meningkatkan kemampuan literasi sains peserta didik SMA Negeri 1 Labuapi. Jenis penelitian yang digunakan adalah Pra-eksperimen, dengan desain one group pretest-posttest design. Populasi penelitian adalah seluruh siswa kelas X MIPA (26 orang). Teknik pengambilan sampel menggunakan sampel jenuh. Data dianalisis menggunakan Uji t (paired sample t test) dan uji N-gain. Hasil penelitian menunjukan bahwa: (1) terdapat perbedaan rata-rata pretest dan postest kemampuan literasi sains dengan perolehan rata-rata pretest 31,85 dan posttest 72,65 . Hasil perhitungan uji t menghasilkan nilai signifikansi $0,000<0,05$, sehingga keputusannya adalah Ho ditolak dan Ha diterima; (2) penerapan model pembelajaran think talk write terintegrasi kearifan lokal berbasis outcame based education melalui penggunaan media online cukup efektif dalam meningkatkan kemampuan literasi sains peserta didik SMA Negeri 1 Labuapi. Hal ini dibuktikan dari perolehan rata-rata skor $\mathrm{N}$-gain literasi sains sebesar $60,6 \%$ termasuk dalam kategori cukup efektif.
\end{abstract}

Kata Kunci: Think Talk Write, Literasi Sains

\begin{abstract}
This study aims to determine: 1. the difference between the average pretest and posttest scores of scientific literacy skills. In the test, the integrated think talk write learning model integrated local wisdom based outcome-based education through the use of online media for students at SMA Negeri 1 Labuapi was applied; 2. whether the application of the think talk write learning model integrated local wisdom based on outcome-based education through the use of online media is effective in increasing the scientific literacy skills of students. This type of research is pre-experimental, with a one-group pretest-posttest design. The study population was all students of class X MIPA (26 people). The sampling technique uses saturated samples. Data were analyzed using a t-test (paired-sample t-test) and an $\mathrm{N}$-gain test. The results showed that: (1) there was a difference in the average pretest and posttest of scientific literacy skills with the average pretest 31.85 and posttest 72.65 . The results of the t-test calculation yield a significance value of $0.000<0.05$. It means that applying the think talk write learning model is quite effective in improving students' scientific literacy skills at SMA Negeri 1 Labuapi. It is evidenced by acquiring an average $\mathrm{N}$-gain score of $60.6 \%$ of scientific literacy, which is categorized as quite effective.
\end{abstract}

Keywords: Think Talk Write, Science Literacy

\section{PENDAHULUAN}

Pandemi covid-19 menjadi persoalan multidimensi yang dihadapi dunia. Mewabahnya suatu penyakit oleh sebuah virus yang dikenal dengan istilah Corona Virus Disease (Covid-19) melanda lebih dari 200 negara didunia, salah satunya ialah Indonesia. Dampak dari Covid-19 menjadi tantangan yang cukup besar terhadap segala aspek kehidupan, termasuk dunia pendidikan.

Pemerintah Indonesia melalui kementerian pendidikan dan kebudayaan dan kementerian Agama RI, menetapkan kebijakan belajar dan bekerja dirumah (Work from home) mulai pertengahan maret 2020. Hal ini sesuai dengan keputusan menteri pendidikan dan kebudayaan republik Indonesia terkait surat edaran no 4 tahun 2020 tentang pelaksanaan kebijakan pendidikan dalam masa darurat penyebaran Covid-19. Kondisi ini menuntut lembaga pendidikan yang mengharuskan kegiatan pembelajaran tetap berjalan meskipun peserta didik berada dirumah untuk melakukan inovasi dalam proses pembelajaran yakni dengan melakukan pembelajaran secara online atau daring (dalam jaringan) [1]. 
Pembelajaran dengan memanfaatkan media online pada situasi pandemi ini merupakan proses pembelajaran yang efektif guna memutus rantai penyebaran Covid-19. Selain itu, memanfatan media online dapat memberikan dampak positif bagi pendidik guna mengasah keterampilan untuk menghadapi tantangan pembelajaran abad 21 yang salah satunya menuntut pendidik dan peserta didik memiliki kemampuan literasi sains.

Literasi sains sangat penting dikuasai oleh peserta didik dalam kaitannya dengan cara peserta didik dapat memahami lingkungan hidup, kesehatan, ekonomi dan masalah-masalah lainnya yang dihadapi oleh masyarakat modern yang sangat bergantung pada teknologi dan kemajuan serta perkembangan ilmu pengetahuan dan teknologi [2].

Saat ini posisi kualitas peserta didik Indonesia di dunia internasional dalam hal kemampuan literasi sains sangat rendah, berdasarkan hasil studi internasional Programme For International Student Assessment (PISA) pada tahun 2018 terjadi penurunan nilai PISA dibandingkan tahun 2015 dengan skor rata-rata 371, yakni berada pada peringkat ke 74 [3]. Rendahnya kemampuan literasi sains peserta didik disebabkan oleh beberapa faktor diantaranya pembelajaran masih didominasi oleh guru (teacher center), pemilihan model dan metode pembelajaran belum memfasilitasi literasi sains siswa. pembelajaran kurang melibatkan siswa secara aktif dalam mengkonstruk pengetahuannya [4]. Oleh karena itu, pentingnya literasi sains peserta didik harus diperhatikan sehingga untuk meningkatkan kemampuan literasi sains peserta didik ditengah pandemi Covid-19 adalah menerapkan model pembelajaran yang tepat dan mampu membangun kemampuan literasi sains, salah satunya ialah model pembelajaran kooperatif tipe think talk write terintegrasi kearifan lokal berbasis outcame based education.

Model pembelajaran kooperatif tipe think talk write terintegrasi kearifan lokal berbasis outcame based education merupakan model pembelajaran yang memiliki 3 tahap pembelajaran yang mampu mendukung pencapaian aspek kemampuan literasi sains, yaitu tahap think (berpikir), talk (berbicara), dan write (menulis). Model pembelajaran think talk write mendorong peserta didik untuk berpikir, berbicara, dan kemudian menuliskan berkenaan dengan suatu topik. Model pembelajaran ini juga membantu siswa dalam mengumpulkan dan mengembangkan ide-ide melalui percakapan terstruktur [5]. Pelaksanaan model pembelajaran think talk write dapat diintegrasikan dengan kearifan lokal, dimana konsep kearifan lokal berupa awik-awik desa Sesaot Narmada yang diangkat dalam penelitian ini akan diterapkan sebagai sumber belajar dan juga menjadi salah satu solusi yang dapat diangkat oleh peserta didik dalam memecahkan permasalahan pada materi keanekaragaman hayati. Sehingga diharapkan mampu meningkatkan kemampuan literasi sains.
Menurut [6] pendidikan sains dapat dikembangkan dengan bertumpu pada keunikan dan keunggulan suatu daerah, termasuk budaya lokal. Aspek budaya lokal dalam pembelajaran dapat meningkatkan efektivitas proses pembelajaran [7].

Pengintegrasian budaya lokal ke dalam pembelajaran penting dilakukan karena dapat memudahkan peserta didik memahami konsep materi yang dipelajari sehingga pengetahuan dan ilmu yang didapatkan memiliki arti yang dapat dimanfaatkan menjadi problem solver dari permasalahan yang dihadapi. Selain itu, mampu menumbuhkan karakter peserta didik yang lebih menghargai berbagai budaya yang ada dan berusaha untuk melestarikannya.

Tolak ukur keberhasilan proses pembelajaran dapat dilihat dari capaian hasil dan proses pembelajaran. Hasil dari proses pembelajaran tidak hanya menguasai pengetahuan konseptual tetapi peserta didik dituntut untuk memiliki pengetahuan, sikap dan keterampilan dari hasil proses pembelajarannya. Ketiga domain tersebut harus dimiliki oleh peserta didik. outcome based education atau yang disebut dengan pendidikan berbasis hasil adalah pendekatan yang berpusat pada peserta didik, berorientasi pada hasil untuk pendidikan dan pelatihan yang dibangun di atas gagasan bahwa semua peserta didik perlu dan dapat mencapai potensi penuh mereka meskipun tidak secara bersamaan [8].

Uraian tersebut menginspirasi penulis untuk melakukan penelitian yang dirumuskan dalam judul "Pengaruh Model Pembelajaran Think Talk Write Terintegrasi Kearifan Lokal Berbasis Outcame Based Education Melalui Penggunaa Media Online Terhadap Kemampuan Literasi Sains Peserta Didik di SMA Negeri 1 Labuapi”.

Penelitian ini bertujuan untuk mengetahui apakah terdapat perbedaan antara nilai rata-rata pretest dan posttes kemampuan literasi sains dengan menerapkan model pembelajaran think talk write terintegrasi kearifan lokal berbasis outcame based education melalui penggunaan media online peserta didik di SMA Negeri 1 dan apakah penerapan model pembelajaran think talk write terintegrasi kearifan lokal berbasis outcame based education melalui penggunaan media online efektif dalam meningkatkan kemampuan literasi sains peserta didik SMA Negeri 1 Labuapi”.

\section{METODE PENELITIAN}

Jenis penelitian yang digunakan dalam penelitian ini adalah Pra-eksperimen. Desain penelitian yang digunakan adalah one group pretestposttest design. Penelitian dilaksanakan di SMAN 1 Labuapi pada semester ganjil tahun ajaran 2020/2021. Populasi dalam penelitian ini seluruh peserta didik kelas $\mathrm{X}$ jurusan IPA yang terdiri dari 1 kelas dengan jumlah sebanyak 26 peserta didik. Pengambilan sampel menggunakan sampel jenuh. Teknik pelaksanaan penelitian menggunakan aplikasi WhatsApp, google drive dan google form. 
Pelaksanaan pembelajaran terdapat pada video pembelajaran sesuai dengan sintaks Model Pembelajaran yang terdiri dari 3 tahapan yaitu tahap think, tahap talk dan tahap write. Pengumpulan data dilakukan dengan menggunakan tes. Analisis data dilakukan dengan uji t (paired sample t test) dengan menggunakan SPSS 17.0 dan uji N-gain. Adapun persamaan untuk $N$-gain dengan skor ideal 100 adalah sebagai berikut:

$$
\mathrm{N}-\text { Gain }=\frac{\text { Skor postest }- \text { skor pretest }}{\text { Skor ideal-skor pretest }}
$$

Tabel tafsiran efektifits $N$-gain dalam presentase terdapat pada tabel 1 berikut:

Tabel 1: Tafsiran efektifitas $N$-gain

\begin{tabular}{cc}
\hline Presentase (\%) & Tafsiran \\
\hline$<40$ & Tidak efektif \\
$40-45$ & Kurang efektif \\
$56-75$ & Cukup Efektif \\
$>76$ & Efektif \\
\hline
\end{tabular}

\section{HASIL DAN PEMBAHASAN}

Keterlaksanaan model pembelajaran didasari dengan pengamatan oleh guru selama proses pembelajaran berlangsung dan selanjutnya pengamat menuliskan hasil pengamatannya dengan mengisi lembar observasi keterlaksanaan model pembelajaran yang dibuat berdasarkan RPP. Pengamatan dilakukan dalam 3 kali pertemuan selama pembelajaran berlangsung. Hasil observasi keterlaksanaan model pembelajaran think talk write terintegrasi kearifan lokal berbasis outcame based education melalui penggunaan media online dapat dilihat melalui tabel 2.

Berdasarkan tabel diatas, dapat dilihat bahwa presentase keterlaksanaan model pembelajaran mencapai $90 \%$ untuk pertemuan-1 dan mengalami peningkatan pada pertemuan ke-2 dan petermuan ke-3 yaitu sebesar $100 \%$. Berdasarkan kategori keterlaksanaan model pembelajaran yang telah ditentukan sebelumnya, maka keterlaksanaan model pembelajaran think talk write terintegrasi kearifan lokal berbasis outcame based education melalui penggunaan media online telaksanana dengan sangat baik. Hal ini berarti proses pembelajaran berjalan dengan baik dan sesuai dengan tahapan-tahapan yang harus dilakukan

Hasil analisis kemampuan literasi sains menunjukkan rata-rata nilai pretest dan posttes kemampuan literasi sains dapat divisualisasikan pada tabel 3 .

Berdasarkan tabel diatas menunjukkan bahwa dari 26 peserta didik yang diberikan pretest sebelum penerapan model pembelajaran pada umunya memiliki tingkat kemampuan literasi sains yang cenderung sangat rendah dengan rata-rata sebesar 31.85 dan standar deviasi 10.30 , nilai tertingginya adalah 53 dan nilai terendahnya 20, sedangkan tingkat kemampuan literasi sains peserta didik yang diberikan posttest pada umumnya cenderung tinggi dengan rata-rata sebesar 72.65 dengan standar deviasi 13.95, nilai tertingginya adalah 93 dan nilai terendahnya adalah 47.

Klasifikasi peningkatan kemampuan literasi sains dengan melakukan uji skor gain untuk menunjukkan nilai gain peserta didik dapat ditunjukan pada tabel 4 .

Tabel 2. Rekapitulasi keterlaksanaan model pembelajaran think talk write terintegrasi kearifan lokal berbasis OBE melalui penggunaan media online

\begin{tabular}{ccccc}
\hline Pertemuan ke- & Skor Pencapaian & Skor Max & Skor Akhir & Interpretasi \\
\hline I & 18 & 20 & 90 & Sangat Baik \\
II & 20 & 20 & 100 & Sangat Baik \\
III & 20 & 20 & 100 & Sangat Baik \\
Rerata & 19.3 & 20.0 & 96.7 & Sangat Baik \\
\hline
\end{tabular}

Tabel 3. Hasil pretest dan posttes keterampilan proses sains

\begin{tabular}{lcc}
\hline \multicolumn{1}{c}{ Statistik } & Pre-test & Pos-test \\
\hline Ukuran Sampel & 26 & 26 \\
Skor Ideal & 100 & 100 \\
Skor maksimum & 53 & 93 \\
Skor minimum & 20 & 47 \\
Skor rata-rata & 31.85 & 72.65 \\
Rentang skor & 33 & 47 \\
Standar Deviasi & 10.30 & 13.95 \\
\hline
\end{tabular}


Tabel 4. Klasifikasi Skor gain kemampuan literasi sains

\begin{tabular}{llll}
\hline Koefisiesn gain & Jumlah siswa & Persentase & Klasifikasi \\
\hline $\mathrm{g} \geq 0,7$ & 12 & $46 \%$ & Tinggi \\
$0,3 \leq \mathrm{g}<0,7$ & 13 & $50 \%$ & Sedang \\
$\mathrm{g}<0,3$ & 1 & $4 \%$ & Rendah \\
Jumlah & 26 & $100,00 \%$ & \\
Rata-rata & 0,61 & & Sedang \\
\hline
\end{tabular}

Tabel 5. Hasil uji hipotesis kemampuan literasi sains

\begin{tabular}{|c|c|c|c|c|c|c|c|}
\hline \multirow{3}{*}{$\begin{array}{l}\text { Pre } \\
\text { Dan }\end{array}$} & \multicolumn{2}{|c|}{ Paired Differences } & \multirow[b]{2}{*}{$\begin{array}{l}\text { Std.error } \\
\text { mean }\end{array}$} & \multirow[b]{2}{*}{$\begin{array}{l}95 \% \text { confidence } \\
\text { interval of the } \\
\text { difference }\end{array}$} & \multirow[b]{2}{*}{$\mathrm{t}$} & \multirow[b]{2}{*}{$\mathrm{df}$} & \multirow[b]{2}{*}{ Sig.(2-tailed) } \\
\hline & Mean & $\begin{array}{l}\text { Std.dev } \\
\text { iasion }\end{array}$ & & & & & \\
\hline & & & & Lower & & & \\
\hline Post & $-40,808$ & 12,139 & 2,381 & $-35,905$ & $-17,141$ & 25 & .000 \\
\hline
\end{tabular}

Berdasarkan tabel diatas menunjukkan bahwa terdapat 12 peserta didik atau $46 \%$ dengan peningakatan lebih dari atau sama dengan 0,7 yang berarti bahwa peserta didik tersebut dalam proses pembelajarannnya mengalami peningakatan kemampuan literasi sains yang tergolong tinggi. Terdapat 13 peserta didik atau 50\% mengalami peningkatan yang tergolong sedang. Sisanya 1 peserta didik atau 4\% dengan peningkatan kurang 0,3 tergolong rendah. Rata-rata peningkatan kemampuan literasi sains peserta didik setelah diberikan pembelajaran dengan menggunakan model pembelajaran think talk write terintegrasi kearifan lokal berbasis outcame based education melalui penggunaan media online adalah 0,61 yang berarti berada pada klasifikasi sedang.

Berdasarkan tabel 5 diperoleh bahwa nilai $\mathrm{t}_{\text {hitung }}=-17,141 . \mathrm{t}_{\text {hitung }}$ bernilai negatif ini disebabkan karena nilai rata-rata kemampuan literasi sains pretes lebih rendah dari pada nilai rata-rata postes, dalam konteks ini kasus seperti ini maka nilai $t_{\text {hitung negatif }}$ dapat bermakna positif, sehingga nilai $t_{\text {hitung }}$ menjadi 17,141 . Karena nilai $t_{\text {hitung }}=17,141>t_{\text {tabel }}=2,060$ dengan nilai signifikansi (2-tailed) adalah 0,000 < 0,005, maka Ho ditolak dan Ha diterima, sehingga dapat dikatakan bahwa terdapat perbedaan rata-rata yang signifikan antara pretes dan postes kemampuan literasi sains.

Uji efektivitas model pembelajaran think talk write terintegrasi kearifan lokal berbasis Outcame Based Education (OBE) melalui penggunaan media online dilakukan dengan uji normalisasi Gain $(\mathrm{N}$ Gain). Hasil dari perhitungan uji $N$-gain ditunjukan pada tabel 6 .

Tabel 6. Hasil perhitungan uji N-Gain skor

\begin{tabular}{cc}
\hline No & $\begin{array}{c}\text { Hasil perhitungan } \text { uji } \mathbf{N} \text {-gain score } \\
\text { Kemampuan literasi sains }\end{array}$ \\
\cline { 2 - 2 } Rata-rata & 60.58 \\
Minimal & 27.40 \\
Maksimal & 85.11 \\
\hline
\end{tabular}

Berdasarkan hasil uji N-gain score diatas, menunjukkan bahwa nilai rata-rata $\mathrm{N}$-gain score penerapan model pembelajaran untuk kemampuan literasi sains adalah sebesar 60,58 atau 60,6\% termasuk kedalam kategori cukup efektif.

Penelitian yang telah dilakukan dengan menggunakan model think talk write terintegrasi kearifan lokal berbasis outcame based education melalui penggunaan media online pada materi keanekaragaman hayati pada peserta didik kelas X di SMAN 1 Labuapi, menunjukkan bahwa kemampuan literasi sains peserta didik meningkat. Peningkatan kemampuan literasi sains peserta didik terlihat dari rata-rata pretest atau nilai rata-rata sebelum kegiatan pembelajaran adalah sebesar 31,85 yang meningkat menjadi 72,65 pada posttest atau nilai rata-rata sesudah kegiatan pembelajaran. Hasil dari paired sample $t$ test juga menyatakan bahwa model think talk write terintegrasi kearifan lokal berbasis outcame based education melalui penggunaan media online dapat meningkatkan kemampuan literasi sains dengan nilai signifikansi yaitu 0,000 .

Adanya pengaruh model pembelajaran think talk write terintegrasi kearifan lokal berbasis outcame based education melalui penggunaan media online dalam meningkatkan kemampuan literasi sains disebabkan karena model think talk write memungkinkan peserta didik melatih kemampuan literasi sains karena difasilitasi dengan kegiatan pembelajaran mengarah pada stimulus kemampuan literasi sains peserta didik. Secara utuh bahwa kegiatan literasi sains dalam strategi think talk write adalah kegiatan berpikir hingga menulis. Hal ini sejalan dengan yang disampaikan [9] kemampuan literasi adalah kemampuan sinergis yang intinya adalah perpaduan kemampuan membaca-berpikirmenulis. Hal yang sama juga diungkapkan oleh [10] menyatakan bahwa peningkatan literasi sains tidak hanya mengacu pada pemahaman struktur ilmu pengetahuan dan teknologi tetapi hubungan mereka dengan lingkungan masyarakat. 
Model think talk write terintegrasi kearifan lokal berbasis outcame based education melalui penggunaan media online dapat menfasilitasi peserta didik untuk mencapai kompetensi literasi yang terdiri dari menjelaskan fenomena secara ilmiah, mengevaluasi dan mendesign penyelidikan ilmiah, dan interpretasi dan membuktikan data secara ilmiah. Hal ini dapat dilihat pada langkah-langkah pelaksanaan pembelajaran yang telah dilakukan.

Indikator literasi sains menjelaskan fenomena secara ilmiah. Menurut [3] kompetensi menjelaskan secara ilmiah dibutuhkan peserta didik untuk mengingat kembali konten pengetahuan yang tepat pada keadaan yang diberikan dan menggunakannya untuk menginterpretasikan dan menyediakan penjelasan pada fenomena yang menarik. Pada implementasi tahap think talk write yang memenuhi kriteria pencapaian kompetensi ini terdapat pada fase think (berpikir). Tahap pembelajaran tersebut, peserta didik diminta mengamati suatu kejadian atau fenomena dalam kehidupan sehari-hari. Pada tahap ini peserta didik dipandu membangun kepekaannya terhadap kejadian atau fenomena yang terjadi dengan cara memberikan motivasi agar peserta didik meningkatkan kemampuan dalam mengajukan pertanyaan. Hal ini sejalan dengan pendapat [11] menyatakan pembelajaran literasi tidak dapat terlepas dari aktifitas berpikir, membaca bagian dari proses berpikir aktif untuk mendapatkan sebuah informasi. Tahap think melatih peserta didik dapat memberikan dan membangun ide gagasan dari proses mengamati dan membaca yang sebelumnya dilakukan.

Indikator literasi sains mengevaluasi, mendesign penyelidikan ilmiah, interpretasi data dan membuktikan data secara ilmiah. Menurut [12] kompetensi mengevaluasi dan mendesign penyelidikan ilmiah dibutuhkan untuk mengevaluasi laporan dari penemuan dan investigasi secara kritis, Indikator ini menuntut peserta didik membuat kesimpulan dan menafsirkan bukti ilmiah. Pada implementasi tahap think talk write yang memenuhi kriteria pencapaian kompetensi ini terdapat pada fase talk (berbicara) dan write (menulis). Tahap talk ialah mengkomunikasikan dari kegiatan membaca yang dilakukan sebelumnya. Kegiatan pada tahap talk mengarahkan peserta didik mengambil keputusan dari informasi yang dibaca, untuk mngetahui kebenaran dari apa yang dibaca dengan interpretasi orang lain, kemudian dicari keputusan yang tepat terkait informasi tersebut untuk didiskusikan atau dikomunkasikan dengan guru maupun dengan teman kelompoknya, dari kegiatan berbicara (talk) kemudian dilanjutkan dengan kegiatan menulis (write) hasil diskusi pada lembar kerja yang sudah disediakan. Aktivitas menulis berarti mengkonstruksi ide, setelah berdiskusi antar teman dan kemudian menggunagkapnya melalui tulisan. Menurut [11] menyatakan proses menulis merupakan bagian yang tidak dapat terpisah dari literasi. Setelah seseorang membaca hasil informasi yang didapatkan dapat dituangkan dalam bentuk tulisan. Dari kegiatan kegiatan berbicara (talk) dan menulis (write) memungkinkan dapat membantu peserta didik memiliki kemampuan mengingat lebih baik dalam memahami materi yang diberikan. Hal ini dikarenakan selain berbicara atau berdiskusi, peserta didik juga menuliskan kembali berkenaan dengan topik pembelajaran sehingga memungkinkan adanya pengulangan dalam proses pembelajaran, dimana semakin sering mengulang-ulang kembali sesuatu kegiatan maka semakin melekat dimemori peserta didik sehingga peserta didik akan memiliki kemampuan mengingat yang lebih baik. Hal ini sejalan dengan pendapat [13] menyatakan tingginya tingkat aktivitas peserta didik dengan menggunakan semua panca indera baik itu komunikasi dan tulisan akan mampu meningkatkan daya ingat.

Terkait efektivitas model pembelajaran think talk write terintegrasi kearifan lokal berbasis outcame based education melalui penggunaan media online termasuk kedalam kategori cukup efektif yaitu dengan nilai rata-rata persen $\mathrm{N}$-gain sebesar 60,58. Keefektifan model think talk write terintegrasi kearifan lokal berbasis outcame based education melalui penggunaan media online disebabkan karena model think talk write memiliki karakteristik dimana model tersebut melibatkan peserta didik untuk berperan aktif dalam setiap tahapan proses pembelajaran. Hal tersebut sejalan dengan pendapat [11] menyatakan strategi think talk write melibatkan peran aktif siswa dalam proses pembelajaran, siswa dituntut untuk mampu menguasai materi pembelajaran melalui proses individual dan kerjasama sosial. Hal yang sama juga dikemukakan oleh [14] bahwa strategi model pembelajaran think talk write dapat didefinisikan sebagai sistem kerja atau belajar kelompok yang terstruktur, sehingga dalam strategi ini kegiatan kerjasama dan komunikasi menjadi kunci pokok kegiatan. Selain itu, penerapan model pembelajaran think talk write juga dapat membantu peserta didik menumbuhkan kemandirian belajar karena peserta didik diberikan lembar kerja terstruktur yang akan didiskusikan bersama kelompoknya sehingga memudahkan peserta didik dalam mengikuti pembelajaran secara online. Hal ini sejalan dengan pendapat [15] yang menyatakan bahwa model pembelajaran think talk write memberikan waktu yang cukup banyak untuk siswa belajar mandiri karena model pembelajaran tersebut lebih banyak untuk menuntut siswa berdiskusi. Model pembelajaran tersebut juga berorientasi pada proyek yang terdiri dari tugas-tugas sehingga cocok diterapkan dalam proses pembelajaran secara online dimasa pandemi Covid-19 ini. Hal ini sejalan pendapat [16] menyatakan pembelajaran online berbasis proyek dapat menjadi salah satu solusi dalam mengoptimalkan pembelajaran khususnya ditengah terjadinyanya pandemi covid-19.

Pengintegrasian budaya lokal ke dalam pembelajaran penting dilakukan karena 
pengintegrasian budaya lokal dalam pembelajaran akan mampu mensinergikan antar budaya yang dimiliki oleh peserta didik dan materi-materi yang akan dipelajari sehingga ketika materi disampaikan, peserta didik sudah memiliki pengetahuan awal, khususnya tentang budaya lokal yang berkaitan dengan materi yang dipelajari, sebagaimana pendapat [17-19] menegaskan bahwa keberhasilan proses pembelajaran sains disekolah sangat dipengaruhi oleh latar belakang budaya yang dimiliki oleh peserta didik atau masyarakat dimana sekolah tersebut berada. Model pembelajaran think talk write terintegrasi kearifan lokal dengan menjadikan kearifan lokal sebagai sumber belajar akan lebih memudahkan peserta didik memahami konsep materi yang dipelajari sehingga pengetahuan dan ilmu yang didapatkan memiliki arti yang dapat dimanfaatkan menjadi problem solver dari permasalahan yang dihadapi. Konsep biologi yang bersifat konkret dapat didukung dengan adanya integrasi budaya lokal ke dalam sains di sekolah akan dapat mempermudah peserta didik dalam mencari informasi semaksimal mungkin tentang materi pelajaran yang akan dipelajari karena kedekatan peserta didik dengan kehidupan nyata. Hal ini sesuai dengan pendapat [13] menyatakan Model pembelajaran think talk write membantu guru mengaitkan materi yang diajarkan dengan situasi dunia nyata peserta didik dan mendorong peserta didik membuat hubungan antara pengetahuan yang dimilikinya dengan penerapannya dalam kehidupan sehari-hari. Selain dari pada itu outcame pembelajaran dari tanggapan peserta didik pada proses pembelajaran ini dapat dilihat dari hasil belajar yang dapat dijelaskan oleh peserta didik dengan mengintegrasikan beberapa pemecahan masalah dengan kearifan lokal awik-awik desa sesaot dalam melestarikan keanekaragaman hayati yang ada didaerah tersebut. Menurut [20] pembelajaran yang dilakukan dengan mengakitkan lingkungan tempat tinggal peserta didik atau terkait dengan situasi nyata dunia sekitar peserta didik akan menajdikan pembelajaran lebih bermakna.

\section{KESIMPULAN}

Berdasarkan hasil analisis data dan pembahasan dapat disimpulkan bahwa terdapat adanya perbedaan rata-rata antara pretes dan postes terhadap kemampuan literasi sains dan berpikir kritis peserta didik yang artinya ada pengaruh model pembelajaran think talk write terintegrasi kearifan lokal berbasis outcame based education melalui penggunaan media online terhadap kemampuan literasi sains peserta didik di SMA Negeri 1 labuapi. Model pembelajaran think talk write terintegrasi kearifan lokal berbasis outcame based education melalui penggunaan media online cukup efektif dalam meningkatkan kemampuan literasi sains peserta didik SMA Negeri 1 Labuapi.

\section{DAFTAR PUSTAKA}

[1] Jamaluddin, D., Ratnasih, T., Ginawan, H., \& Paujiah, E. (2020). Pembelajaran daring masa pandemi Covid-19 pada calon guru: hambatan, solusi dan proyeksi. $L P 2 M$.

[2] Toharudin, U., Hendrawati, S., \& Rustaman, A. (2011). Membangun Literasi Sains Peserta Didik. Bandung: Humaniora.

[3] OECD. (2019). PISA 2018 Result Combined Executive Summaries Volume I, II, III. New York: Columbia Univerity.

[4] Fatmawati, I. N, \& Utari, S. (2015). Penerapan Levels Of Inquiry Untuk Meningkatkan Literasi Sains Siswa SMP Tema Limbah Dan Upaya Penanggulannya. Edusains. 7(2), 151-159.

[5] Wirawan, I. K. (2016). Model Pembelajaran Koperatif TTW (Think Talk Write). Untuk Meningkatkan Interaksi Sosial Dan Pemahaman Konsep Konsep Fisika Siswa. Universitas Pendidikan Ganesha Fakultas Matematika Dan Ilmu Pengetahuan Alam Jurusan Pendidikan Fisika.

[6] Kartono, H., \& Bujang, G. (2010). Penelusuran Budaya dan Teknologi Lokal dalam Rangka Rekonstruksi dan Pengembangan Sains di Sekolahdasar. Pontianak: FKIP Universitas Tanjung pura.

[7] Suastra, I. W., \& Yasmini, L. P. B. (2013). Model Pembelajaran Fisika Untuk Mengembangkan Kreativitas Berpikir dan Karakter Bangsa Berbasis Kearifan Lokal Bali. Jurnal Pendidikan Indonesia, 2(2), 221-235.

[8] Miles, B. M., \& Huberman, A. M. (2007). Analisis Data Kualitatif. Jakarta: Universitas Indonesia Press.

[9] Eanes, R. 1997. Content Area Literacy: Teaching For Today and Tomorrow. Al-bany: Delmar Publisher.

[10]Rohmawati, E.R.,Wahono, W., \& Rudiana, A. (2018). Membangun Kemampuan Literasi Sains Peserta didik Melalui Pembelajaran Berkonteks Socio Scientific Issues Berbantuan Media. Jurnal Penelitian Pendidikan IPA. 3(1), 8-14.

[11] Putriani, I., Suwignyo, H., \& Hasanah M. (2017). Prosiding TEP \& PDs Transformasi pendidikan Abad 21. Pembelajaran literasi pada siswa sekolah dasar melalui strategi Think Talk Write (TTW). 715-720.

[12] Nugraheni, N. C., Paidi., \& Triatmanto. (2017). Kemampuan Literasi Sains Kelas X SMA Negeri Mata Pelajaran Biologi Berdasarkan Topografi Wilayah Gunung Kidul. Jurnal Prodi Pendidikan Biologi, 6(5), 261-271.

[13] Muhsin, L. B., Sukib, \& Laksminawati, D. (2019). Pengaruh Model Pembelajaran Think Talk Write (TTW) Berpikir Bierbicara Menulis Terhadap Hasil Belajar Siswa Pada Mata Pelajaran Kimia Materi Koloid. Jurnal Chemistry Education Practice . 2(2), 37-43. 
[14] Resdiyanti, I. (2013). Penerapan Model Pembeljaran Kooperatif Tipe Think Talk Write (TTW) Untuk Meningkatkan Kemampuan Kritis Dan Hasil Belajar Geografi Siswa Kelas XI IPS 1 SMA Negeri 1 Sumbul. Skripsi. Jurusan Pendidikan Geografi Universitas Negeri Medan.

[15] Asy'ari. (2016). Model pembelajaran Think Talk Write (TTW) berbasis assessment for learning (AFL) melalui penilaian teman sejawat meningkatkan kemampuan belajar siswa kelas VIII. Jurnal Pendidikan matematika. 2(2), 116125.

[16] Abidin, Z., Rumansyah., \& Arizona K. (2020). Pembelajaran Online Berbasis Proyek Salah Satu Solusi Kegiatan Belajar Mengajar di Tengah Pandemi Covid-19. Jurnal Ilmiah Profesi Pendidikan, 5(1), 64-70.

[17] Marheni, N P., \& Suardana, I N. (2014). Pembelajaran Inkuiri Terbimbing Berbasis Budaya Lokal Pada Pembelajaran Sains Kimia SMP. Jurnal Wahana Matematika dan Sains, 8(2), 87-100.

[18] Utari, R., Andayani, Y., Savalas, L. R. T., \& Anwar, Y. A. S. (2021). Pemanfaatan Hasil Pengembangan Modul Kimia Berbasis Etnosains Untuk Menanamkan Sikap Konservasi Lingkungan di Sekolah MAN 2 Lombok Tengah. Jurnal Pengabdian Magister Pendidikan IPA, 4(1).

[19] Rahmatih, A. N., Maulyda, M. A., \& Syazali, M. (2020). Refleksi nilai kearifan lokal (local wisdom) dalam pembelajaran sains sekolah dasar: Literature review. Jurnal Pijar Mipa, 15(2), 151-156.

[20] Sya'ban, F. M. (2014). Kepedulian Lingkungan Dengan Pembelajaran IPA Terintegrasi Kearifan Lokal. Jurnal Inovasi Pendidikan Sains. 5(2), 8286. 